\title{
Chapter 37 \\ Article 35: Prevention of Abduction, Sale, and Trafficking
}

\author{
Adem Arkadas-Thibert and Gerison Lansdown
}

States Parties shall take all appropriate national, bilateral and multilateral measures to prevent the abduction of, the sale of or traffic in children for any purpose or in any form.

\section{What Did Children Say?}

'There should be strong laws against child abduction and trafficking made by the government to protect the interest of children.' (Africa).

For every child crossing the border, the state must create an administrative document for the consent of the child and his or her parents and caregivers. (Africa).

Governments should train special formidable force in executing duties in rescuing and rehabilitation of victims and prosecuting perpetrator. (Africa).

'Is government encouraging children to speak up about issues?' (Latin America/Caribbean).

\footnotetext{
A. Arkadas-Thibert $(\bowtie)$

Marseille, France

G. Lansdown

Carleton University, Ottawa, ON, Canada 


\section{Overview}

Protection from many forms of exploitation of children, such as intercountry parental abduction, adoption for profit, forced labour, sexual exploitation, and military recruitment, are covered under the Convention. Article 35 adds an extra layer of protection, reinforcing States Parties' obligation to have preventive measures against acts of abduction, traffic, or sale of children, not only across borders but also within their jurisdiction. It recognises that States Parties have wide-ranging national, bilateral, and multilateral obligations of prevention of all acts that render the child into some form of commodity. Therefore, it serves as a supplementary layer of protection for children from commercial exploitation.

Since the Convention was drafted, awareness of all forms of trafficking has become much better understood, while the emergence of the digital environment has exposed children to significantly greater risks in this regard. The Committee, for example, has noted that the globalised online and increasingly mobile world opens up new ways to connect with, solicit, and groom children, as well as viewing online child sexual abuse via live video streaming, distributing child sexual abuse material, and engaging in the sale and sexual exploitation of children in the context of travel and tourism (2019, paras. 2-3). In recognition of the need to strengthen protection of children, in 2000, the Committee published the Optional Protocol to the Convention on the Rights of the Child on the sale of children, child prostitution and child pornography, and in 2019, developed guidelines to enable more effective implementation (2019).

The Travaux Préparatoires of the Convention reveal that it was first suggested to have one composite article combining Articles 34 (commercial sexual exploitation of children), 35, and 36 (all other forms of exploitation) to cover sexual and other related forms of exploitation. However, drafting delegates opted for separate articles to provide a wider and fail-safe protection for children as the sale or traffic of children was wider in scope than that of sexual exploitation (Office of the United Nations High Commissioner for Human Rights and Rädda barnen (Society: Sweden), 2007, pp. 723-737). Neither the Travaux Préparatoires nor Article 35 provide definitions for abduction of, sale of, or trafficking in children. It has, however, been addressed in multiple subsequent international instruments and it is to these other instruments that one can turn for more specific definitions.

Abduction means the removal or the retention of a child in breach of rights of custody internationally and within the borders of the States Party. ${ }^{1}$ In the context of Article 35 , this means any non-familial abductions, as abductions between family members would fall under Article 11 (Gallagher, 2019, p. 1362).

Sale of children means 'any act or transaction whereby a child is transferred by any person or group of persons to another for remuneration or any other consideration.' This definition, from the Optional Protocol on the sale of children, child

\footnotetext{
${ }^{1}$ See the full definition in the Convention on the Civil Aspects of International Child Abduction, Article 3.
} 
prostitution and child pornography, Article 2, clearly interprets sale of children as being a form of exploitation. The Committee has recognised that the sale of children can be not only for sexual exploitation, but also, for example, for the purposes of transfer of organs, engagement in forced labour, and situations in which adoption constitutes the sale of children (UN Committee on the Rights of the Child, 2019, para. 14).

Trafficking in persons means the recruitment, transportation, transfer, harbouring, or receipt of persons, by means of the threat or use of force or other forms of coercion, of abduction, of fraud, of deception, of the abuse of power or of a position of vulnerability, or of the giving or receiving of payments or benefits to achieve the consent of a person having control over another person, for the purpose of exploitation. 'Exploitation shall include, at a minimum, the exploitation of the prostitution of others or other forms of sexual exploitation, forced labour or services, slavery or practices similar to slavery, servitude or the removal of organs.' This definition, from the Protocol to Prevent, Suppress and Punish Trafficking in Persons, Especially Women and Children, supplementing the United Nations Convention against Transnational Organized Crime, Article 3, has been recognised by the Committee and it has acknowledged a number of practices as falling within the scope of Article 35, including sexual exploitation, forced and exploitative labour, begging, forced and temporary marriage, and domestic servitude. Three aspects (action, means, and purpose) must be involved to constitute trafficking (Gallagher, 2019, p. 1364).

In addition, the United Nations Working Group on Contemporary Forms of Slavery has recognised forced marriage as a form of contemporary slavery, trafficking, and sexual exploitation (UN Working Group on Contemporary Forms of Slavery, 2003). The African Charter on the Rights and Welfare of the Child includes the use of children in all forms of begging in Article 29(b). This is a form of exploitation not mentioned in other human rights treaties.

The Committee has noted that abduction, trafficking, and sale of children are linked yet distinct phenomena, but States Parties largely concentrate on trafficking in children to deal with these three different forms of commercial exploitation. This creates a gap in collection of data and subsequent knowledge for States Parties to introduce relevant and targeted measures of prevention (Giammarinaro et al., 2017, para. 16).

\section{General Principles}

Article 2 Every child has the right to be protected from abduction, trafficking, or sale. Certain groups of children are more at risk than adults and/or other children, for example, children of minority gender or sex identities and orientations, children with disabilities, children in institutions, migrant children, children in street situations, and children in other vulnerable or marginalised situations (UN Committee on the Rights of the Child, 2019, para. 13). The Committee has highlighted the gender 
dimension of such offences against children and noted that although most victims are girls, boys are also vulnerable. Despite this, very few support structures for boys are in place (2019, para. 4). States Parties must introduce measures to identify, prevent and protect all such children from abduction, sale, or trafficking.

Article 3 Children's current and future safety is one of the fundamental tenets of the child's best interests (UN Committee on the Rights of the Child, 2013). Effective preventive and protective measures for children must be taken to guarantee the best interest of the child. In particular, in criminal justice systems, the best interests of the child who is a victim of crimes of abduction, sale, or trafficking must be the primary consideration (UN General Assembly, 2001, Article 8, para. 3). This includes decriminalisation of children involved as victims or used as instruments in such crimes.

Article 6 All forms of exploitation of children constitute a threat to the fulfilment of their right to life, survival, and development (UN Committee on the Rights of the Child, 2011, para. 15).

Article 12 Children, including 'child victims of physical or psychological violence, sexual abuse or other crimes,' have the right to be heard in any judicial proceedings, as victims or subjects, and administrative proceedings, as agents to shape policies and actions (UN Committee on the Rights of the Child, 2009, paras. 32, 118-121). Children have rights to access information, including life skills and the knowledge to protect themselves from exploitation, and seek assistance and justice whenever needed. States Parties should seek to include children in the processes of both drafting and implementing legislative and policy measures. Consultations with children must be carried out in an age-appropriate and gender-sensitive manner by adults with the necessary training and resources (UN Committee on the Rights of the Child, 2019, para. 12).

\section{Articles Related or Linked to Article 35}

Article 11 addresses measures to deal with international abductions between family members.

Article 21 protects children from sale in the form of international adoption for the purposes of financial gain.

Article 24(3) requires States Parties to take measures to effectively abolish traditional practices, such as child marriage, as a form of sale of or traffic in children, which are detrimental to the rights and well-being of children.

Article 26 requires States Parties to provide children with available, accessible, and quality social security in accordance with their circumstances and their care providers' resources, and in so doing reduces the child's risk of being in a position of exploitation. 
Article 27 requires States Parties to provide the child with adequate living conditions for their physical, mental, spiritual, moral, and social development. This serves as a preventive and protective measure from abduction, sale, or traffic in children.

Article 32 protects children against trafficking, forced labour, and slavery-like working conditions.

Article 33 protects from the use of children in crimes of illicit substance trafficking.

Article 34 protects from children's use in the sex trade, in prostitution, in the production of pornography, or through forced marriages.

Article 36 protects from all other forms of exploitation, including those involving information and communication technologies.

Article 38 protects children in conditions of war, where children can be forced to become soldiers or servants to armed forces.

Article 39 requires States Parties to provide the child who is exposed to abduction, sale, or trafficking with physical and psychological recovery and social reintegration.

Optional Protocol to the Convention on the Rights of the Child on the involvement of children in armed conflict, esp. Article 3 (2000).

Optional Protocol to the Convention on the Rights of the Child on the sale of children, child prostitution and child pornography (2000).

\section{Relevant Instruments}

UN Protocol to Prevent, Suppress and Punish Trafficking in Persons Especially Women and Children, supplementing the United Nations Convention against Transnational Organized Crime (2000).

Hague Convention on the Civil Aspects of International Child Abduction (1980).

Hague Convention on Protection of Children and Co-operation in Respect of Intercountry Adoption (1993), especially Article 1.

ILO Convention 182, Worst Forms of Child Labour (1999), especially Article 3. American Convention on Human Rights 'Pact of San Jose, Costa Rica' (B-32) (1978), Articles 6 and 19.

African Charter on Human and Peoples' Rights (1981), especially Article 5.

African Charter on the Rights and Welfare of the Child (1990), Article 29.

Inter-American Convention on International Traffic in Minors (1994). 


\section{Attributes}

\section{Attribute One: National, Bilateral, and Multilateral Measures to Prevent Abduction, Traffic, and Sale of Children}

Article 35 provides that States Parties must set up preventive measures to remove risk factors of abduction, traffic, and sale of children, including through national, bilateral, and multilateral level agreements, in order to address the phenomenon both within and beyond the states' borders. Such agreements should involve state agencies, law enforcement actors, judicial authorities, and other relevant stakeholders.

The obligation to prevent abduction, traffic, and sale of children requires that measures are undertaken to identify those groups of children likely to be vulnerable, as well as addressing the political, social, economic, and cultural root causes of that vulnerability. States Parties should provide information and awareness raising of the risks for parents, teachers, and other professionals, mandatory education in schools on how children can keep safe and protect themselves, including online, and effective measures for safe reporting and effective and prompt responses to any reports of such harm (UN Committee on the Rights of the Child, 2019, paras. 37-40).

Access to legal documentation such as birth certificates, to equality education, and strategies to address the particular vulnerabilities of some groups can also serve to protect children. States Parties must adopt measures to address both employer and consumer demand for cheap labour and goods (Gallagher, 2019, p. 1394). Finally, they must undertake regular monitoring and sharing of information about the state of children who are exposed to abduction, sale, or trafficking locally, nationally, and regionally, together with provision of data or supporting research on the issues concerned, and introduce international and national strategies and plans of action to eradicate them.

\section{Attribute Two: Establishing a Protective Legal and Policy Framework}

Article 35 requires States Parties to introduce deterrent, preventive, and reactive legislation and policies, including criminalising trafficking and related offences, together with appropriate sanctions, as well as establishing effective mechanisms of investigation and prosecution for the abduction, traffic, or sale of children. The Committee has emphasised the importance of appropriately trained law enforcement officials for dealing with trafficking in children (2012a, para. 82, 2012b, para. 64). The rules for criminal jurisdiction must ensure that perpetrators can be punished wherever the offences take place, as required in the Optional Protocol on the sale of children, child prostitution and child pornography (UN Committee on the Rights of the Child, 2019, pp. 80-89). 
Prevention efforts, including legislation, must recognise that children exposed to abduction, sale, and trafficking are victims, not criminals. The Committee, for example, has emphasised that victims of trafficking must not be criminalised solely for reasons of their illegal entry or presence in the country' (2005, para. 62, 2010, para. 75, 2016, para. 64 (c)). Where children who are victims of trafficking are subsequently detained for the purposes of safeguarding and protection of their rights, the conditions under which they are cared for must be governed by their best interests and take account of their vulnerability to abuse, victimisation, and further violation of their rights (Gallagher, 2019, p. 1383).

In any criminal proceedings, child victims must be provided with legal representation and counselling, interviews must be held without delay and in a child-friendly environment, and the child's privacy and safety must be protected at all times. Any decision concerning repatriation should take account of the child's safety, availability of care, the child's views, duration of absence from the home country, and the child's right to preservation of identity (UN Committee on the Rights of the Child, 2005, para. 84).

\section{Attribute Three: Protection of Survivors/Victims of Abduction, Sale and Trafficking}

The priority in respect of Article 35 must be to protect children's human dignity and their rights. As enshrined in Article 39 of the Convention, States Parties must take all appropriate measures to promote the recovery and social reintegration of child victims (Hodgkin et al., 2007, p. 538). Article 35 also implies that States Parties must ensure that survivors or victims of the abduction, traffic, or sale are identified, protected, and supported. A comprehensive range of measures are recommended in Article 8 of the Optional Protocol on the sale of children, child prostitution and child pornography, as well as Articles 6 through 8 of the Protocol to Prevent, Suppress and Punish Trafficking in Persons, Especially Women and Children, and further elaborated in the Committee Guidelines to the Optional Protocol. The articles include measures to ensure privacy and confidentiality, physical safety and protection from further harm, access to information, access to justice, being heard effectively, support for recovery, medical, physical and psychological assistance, compensation, and opportunities for repatriation where appropriate.

\section{References}

Gallagher, A. (2019). Article 35: Protection against the abduction, traffic and Sale of children. In J. Tobin (Ed.), The UN convention on the rights of the child: A commentary (pp. 1356-1401). Oxford University Press. 
Giammarinaro, M. G., Buquicchio-de Boer, M., \& UN Secretary General. (2017). Joint report of the Special Rapporteur on the Sale and sexual exploitation of children, including child prostitution, child pornography and other child sexual abuse material; and trafficking in persons, especially women and children. A/72/164. UN. Retrieved November 29, 2020, from http://digitallibrary.un.org/record/1300900

Hodgkin, R., Newell, P., \& UNICEF. (2007). Implementation handbook for the convention on the rights of the child (3rd ed.). New York: UNICEF. Retrieved September 21, 2020, from https:// digitallibrary.un.org/record/620060? $\mathrm{ln}=\mathrm{en}$

Office of the United Nations High Commissioner for Human Rights \& Rädda barnen (Society: Sweden). (2007). Legislative history of the convention on the rights of the child. New York: United Nations. Retrieved from https://digitallibrary.un.org/record/602462? $\mathrm{ln}=\mathrm{en}$

UN Committee on the Rights of the Child. (2005). General Comment No. 6 (2005) Treatment of Unaccompanied and Separated Children Outside their Country of Origin, September 1, 2005, $C R C / G C / 2005 / 6$. Retrieved October 12, 2020, from https://digitallibrary.un.org/record/566055? $\ln =\mathrm{en}$

UN Committee on the Rights of the Child. (2009). General Comment No. 12 (2009) The right of the child to be heard, July 20, 2009, CRC/C/GC/12. Retrieved October 12, 2020 from https:// digitallibrary.un.org/record/671444? $\mathrm{ln}=\mathrm{en}$

UN Committee on the Rights of the Child. (2010). Concluding observations: Argentina, June 21, 2010, CRC/C/ARG/CO/3-4. UN. Retrieved November 29, 2020, from http://digitallibrary. un.org/record/684966

UN Committee on the Rights of the Child. (2011). General Comment No. 13 (2011) The right of the child to freedom from all forms of violence, April 18, 2011,CRC/C/GC/13. Retrieved October 12, 2020, from https://digitallibrary.un.org/record/711722? $\mathrm{ln}=\mathrm{en}$

UN Committee on the Rights of the Child. (2012a). Concluding observations: Canada, December 6, 2012, CRC/C/CAN/CO/3-4. Retrieved October 11, 2020, from https://digitallibrary.un.org/ record $/ 739319 ? \ln =\mathrm{en}$

UN Committee on the Rights of the Child. (2012b). Concluding observations: Madagascar, March 8, 2012, CRC/C/MDG/CO/3-4. UN. Retrieved November 14, 2020, from http://digitallibrary. un.org/record/723341

UN Committee on the Rights of the Child. (2013). General Comment No. 14 (2013) On the right of the child to have his or her best interests taken as a primary consideration (art. 3, para. 1), May 29, 2013, CRC/C/GC/14. Retrieved October 12, 2020, from https://digitallibrary.un.org/record/ $778523 ? \ln =\mathrm{en}$

UN Committee on the Rights of the Child. (2016). Concluding observations: Oman, March 14, 2016, CRC/C/OMN/CO/3-4. UN. Retrieved November 29, 2020, from http://digitallibrary. un.org/record/835003

UN Committee on the Rights of the Child. (2019). Guidelines regarding the implementation of the Optional Protocol to the Convention on the Rights of the Child on the sale of children, child prostitution and child pornography, CRC/C/156. Retrieved November 26, 2020, from https:// undocs.org/en/CRC/C/156

UN General Assembly. (2001). Optional protocols to the Convention on the Rights of the Child on the involvement of children in armed conflict and on the sale of children, child prostitution and child pornography, A/RES/54/263. UN. Retrieved November 29, 2020, from http:// digitallibrary.un.org/record/416571

UN Working Group on Contemporary Forms of Slavery. (2003). Report of the Working Group on Contemporary Forms of Slavery on its 28th session, E/CN.4/Sub.2/2003/31. UN. Retrieved November 29, 2020, from http://digitallibrary.un.org/record/500172 
Open Access This chapter is licensed under the terms of the Creative Commons Attribution 4.0 International License (http://creativecommons.org/licenses/by/4.0/), which permits use, sharing, adaptation, distribution and reproduction in any medium or format, as long as you give appropriate credit to the original author(s) and the source, provide a link to the Creative Commons license and indicate if changes were made.

The images or other third party material in this chapter are included in the chapter's Creative Commons license, unless indicated otherwise in a credit line to the material. If material is not included in the chapter's Creative Commons license and your intended use is not permitted by statutory regulation or exceeds the permitted use, you will need to obtain permission directly from the copyright holder. 